AJIT-e: Online Academic Journal of Information Technology

2018- Informatics and Communication Technologies Special Issue/iletişim ve Bilişim Teknolojileri

Özel Sayı -Cilt/Vol: 9-Sayı/Num: 35

DOI: 10.5824/1309-1581.2018.5.006.x

http://www.ajit-e.org/?menu=pages\&p=details_of_article\&id=381

Received : 12.11 .2018

Editorial Process Begin: 28.11.2018

Published: 19.12.2018

\title{
Ayna Olarak Instagram
}

Emre Biçici, Doktora Öğrencisi, Kocaeli Üniversitesi Iletişim Fakültesi, Kocaeli-TÜRKiYE, emrebcc90@gmail.com

ÖZ

Günümüzde sosyal medya insanlarm iletişim şekillerini değiştirmiş ve kendilerini farklı bir şekilde ifade edebilmelerine olanak vermiştir. Instagram bu uygulamalar arasından en popüler olan uygulamalardan birisidir. Uygulama içerisinde insanlar kendilerini de bir sembole dönüştürerek görseller üzerinden ifade etmektedirler. Bu araştırma Lacan'ın "Ayna Evresi", Roland Barthes'ın göstergebilimi, "Kapitalizmin Mitleri" kavramı ve postmodern tüketim çerçevesinde incelenecektir. Çalışmanın amacı bireylerin Instagram üzerinden yapmış oldukları paylaşımlar ile kimliklerini nasıl ifade ettiklerini anlamaktır.

Anahtar Kelimeler: Sosyal medya, Lacan, Barthes, Psikanaliz, Instagram

\section{Instagram as a Mirror}

\begin{abstract}
Today, social media has changed the way people communicate and they can express themselves in a different way. Instagram is the one of the most popular application among these applications. In the application, people express themselves trough images by transforming themselves into symbols. In this research will be examined in frame with Lacan's mirror stage, Roland Barthes semiotics, myths of capitalism and post modern consumption. The aim of the study is to understand how individuals express their identities with Instagram.
\end{abstract}

Keywords: Social media, Lacan, Barthes, Psychoanalysis, Instagram

\section{Gíriş}

Günümüzde hiç tartışmasız sosyal medya içerisinde Instagram en popüler olan uygulamalardan birisidir. İnsanlar bu uygulama sayesinde kendileri ya da beğenmiş oldukları görselleri paylaşmakta ve bu görseller diğer kişiler tarafından görülmektedir. Bu sayede Instagram kişiler arasında görsel bir ağ kuran bir sosyal medya uygulamasıdır.

Instagram kişinin benliğini ifade edebileceği bir ortamdır. Kişinin kültürel bir varlık olma arayışında yardımcı olan bir sosyal medya uygulaması olarak instagram kurmuş olduğu ağlar sayesinde daha önceleri sosyal ortamlarda kendilerini gösteren kişilerin sosyal medya üzerinden benliklerini ifade etmelerini sağlamaktadır. Instagram üzerinden oluşan bu ifade etme sürecinde çeşitli metalar, mekanlar ve görseller kullanılmaktadır. 
$\mathrm{Bu}$ araştırmada insanların Instagram üzerinden simgesel benliğin temsili çerçevesinde yaptıkları (Kaynağın) kullanıcının paylaşımlar konusundaki düşünceleri Lacan'ın “Ayna Evresi" ve Barthes'ın "Kapitalizmin Mitleri" kavramı merkez alınarak incelenecektir. Çalışmada Lacan'ın Ayna evresi ve Barthes'ın Mit kavramının desteklenmesi için Postmodern tüketim anlayışına değinilmiş ayrıca sanal bir ortam olarak sosyal medya ele alınmıştır.

Araştırmanın amacı bireylerin İnstagram üzerinde yapmış oldukları paylaşımlar üzerinden kimliklerini nasıl ifade ettiklerini Lacan'ın psikanalatik kuramı merkez alınarak açıklamaktır.

\section{LACAN'IN AYNA EVRESI}

Jacques Lacan, Sigmund Freud'tan sonra gelen psikanalisterin, psikanalizin çalışma alanının dışına çıktıklarını söylemiştir. Lacana göre psikanalizin esas çalışma alanı biliç dışıdır. Bu bağlamda Lacan, Freud'un teorisini dilbilim, antropoloji ve felsefeyi kullanarak tekrar okumaktadır (Çoban, 2005:277-278).

Lacan'a göre dil öznelerin inşa edildiği bir yerdir. Dil içerisinde toplumsal ve kültürel pratikler aktarılır. Aynı zamanda dil insanların sosyal kimliklerini, inanış biçimlerini ve düşüncelerini inşa ettikleri bir alandır. Bireyler kendilerini dilin sembolleri üzerinden ifade ederler. Böylelikle dünya ile ilişkiler dil sayesinde kurulmaktadır. Dil, birey var olmadan önce dış dünya tarafından belirlenmiştir ve belirlenmektedir. Birey bu sembolik dünyada kendisini bu dile ayak uydurarak ifade eder (Çoban, 2005:280-282).

Ayna evresi altı ila onsekiz ay arasında ortaya çıkmaktadır. Dönem içerisinde aynaya bakan çocuk kendi imgesinin çekimi altındadır ve onu denetim altına almak istemektedir. Kendi imgesi ile gerçekçiliği karıştıran çocuk zamanla bu imgenin kendisinin bir yansıması olduğunun farkına varmaktadır (Homer, 2013:41). Burada ayna olarak bahsedilen şey su ya da gözden oluşan bir yansıma da olabilir. Lacan'a göre çocuk ben kavramına daha önceden sadece imgesel olarak sahiptir. Aynada kendi görüntüsünü yakalayan çocuk "Bu benim" demektedir. Burada imge için kullanılan "ben" ile simge için kullanılan "ben" kelimesi fransızcada "je" ve "moi" arasındaki ayrım gibidir. Burada bahsedilmekte olan ayrım dil üzerindeki ayrım ile aynı şey değildir. İmgesel düzey içerisinde dil zaten bulunmamaktadır. Dil içerisindeki ben simgesel bir ben iken ayna evresindeki ben imgeseldir (Balkaya, 2013:5355). Çocuk ilk benlik bilincini aynaya bakarak kazanmaktadır. Bütünlük kazanımı deneyimleme üzerine değil, görülme üzerine oluşmaktadır (Mencütekin, 2014:35). Ayna evresi Freud'un Oidipus döneminin gerçekleşmesine denk düşen bir dönemde gerçekleşmektedir (Tura, 2012:182). Burada çocuğun dilin içerisine düşmesi aynı zamanda kültürel bir dünyanın içine girmesi anlamına da gelmektedir (Çoban, 2005:282-283).

Bebeğin dilin içerisine geçmesi ile birlikte birey için gereksinimler dönemi sona ermiş onun yerine istemler dönemi başlamıştır. Kültürel dünyanın ürünlerinden oluşan istemler nesneler ile karşılanabilir bir olgu değildir. Nesnelerin eksikliği onların yerini alan "Simgeler" tarafından karşılanır (Çoban, 2005:282-283). Tura bu konuda şöyle bir yorum yapmaktadır (2012:184) “Lacan'a göre ben'in esas işlevi bir imge ile özdeşleşmek, bir kültürel imge halinde kendini görmektir." 
Bu bağlamda sembollerin nasıl birşeyi temsil ettiğini anlayabilmek için Roland Barthes'ın mit kavramı ve gösterge bilime değinmek yerinde olacaktır. Böylelikle kapitalizmin oluşturmuş olduğu mitlerin kitle iletişim araçları üzerinden toplumları nasıl baştan çıkardığını anlamamıza yardımcı olacaktır.

\section{GÜNÜMÜZ MİTLERİ, GÖSTERGEBİLIM VE REKLAMLAR}

Fransız düşünür Roland Barthes'ın araştırmaları geçmişte sahip olunan mitlerin yanı sıra günümüzde de farkında olmadığımız mitlerin bulunduğunu ve bu mitlerin çeşitli göstergeler üzerinde kendilerini gösterdiğini söylemektedir (Yaylagül, 2010:122-124). Barthes göstergebilimsel serüven isimli kitabında araba, film, el kol hareketi, yemek gibi şeylerin ortak noktasının olduğunu ve hepsinin birer gösterge olduğundan bahsetmektedir. Modern insanın günü bu göstergeleri okuyarak geçmektedir (Barthes, 2012:185).

Barthes çalışmalarında Ferdinand de Sassure'ün çalışmalarından yararlanmıştır. Gösteren ve gösterilen arasındaki ilişkiye bir de düz anlam ve yan anlam kavramlarını getirmiştir. Düz anlamda gösterilende gösterenin zihinde canlandırdığı nesne ya da kavram canlanırken yan anlamda kapitalizmin yaratmış olduğu mitler işlemektedir (Yaylagül, 2010:122-123).

Günümüz mitlerinde gösteren, gösterilen ve göstergeden oluşan üç boyutlu bir çizge bulunmaktadır. Söylen kendisinden önceki göstergeler zincirinden oluşan özel bir dizgedir. İlk dizgedeki gösterge ikinci dizgede gösteren olmaktadır (Barthes, 2011:183-184).

\section{Şekil 1.Barthes'ın Mit ve Gösterge kuramı}

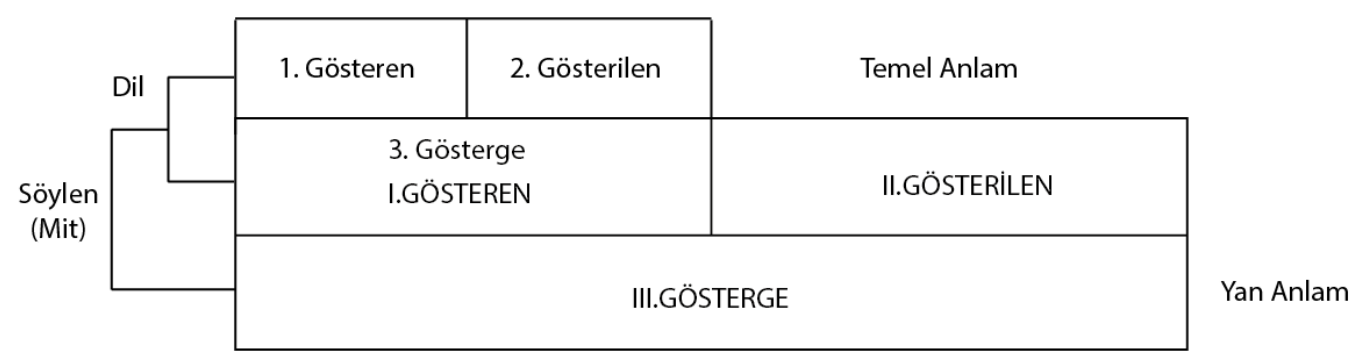

Kaynak: R. Barthes, Çağdaş Söylenler, Çev: T.Yücel, Metis yay. İstanbul 2011, s.184

$\mathrm{Bu}$ durumu Barthes bir örnek üzerinden açıklamaktadır. Berberdedir ve dergi kapağı üzerinde fransa üniforması giymiş bir siyahi görmektedir. Barthes'a göre burada göstergesel dizge içerisinde ön dizgede oluşan görsel yan anlam olarak Fransa'nın büyük bir imparatorluk olduğunu göstermektedir (Barthes, 2011:185).

Bu durumu göz önünde bulundurduğumuzda Lacan'ın bahsetmiş olduğu kendimizi ifade etmemize yarayan simgelere kitle iletişim araçları tarafından anlam yüklenmektedir 
diyebiliriz. Kapitalizmin mitleri, ayna evresi üzerinden ele alındığında çocuğun içine düşmüş olduğu kültürdür.

Levent Yaylagül'e (2010:124)göre "Barthes, Çağdaş kapitalist toplumlarda mitler üretildiğini belirtir. Bu mitler kitleleri baştan çıkarır ve birer taklitçiye dönüştürür." Yaylagül'ün bu sözü ayna evresi ile birlikte düşünüldüğünde bireylerin sembolleri kullanarak kültürel bir imge haline gelmeye çalışmaları düşüncesi ile uyuşmaktadır. Bu mitlerin kitleleri nasıl baştan çıkardığını anlamak için kitle iletişim araçları ile metalara nasıl anlam yüklenildiği ve tüketim ilişkisine değinmek gerekmektedir.

Günümüzde tüketim anlayışı semboller dizisinin tüketiciye anlamlı gelmesine bağlı oluşmaktadır. Bu semboller üretici firmaların üretmiş oldukları malları tüketicilere diretmesi ile gerçekleşmemektedir. Satışın gerçekleşebilmesi için reklam ve yapılan promosyonların tüketicinin arzularına seslenmesi gerekmektedir (Bocock, 2009:62).

Günümüzde televizyon ve sinema gibi mecralar kendimiz hakkındaki düşünceleri ve nasıl düşünmemiz gerektiğini etkilemektedir (Fulford, 2014:109). Bu durum göz önünde bulundurulduğunda, bu mecralarda kendisini gösteren reklamlar aynı zamanda bir sinema filmi gibi anlamda oluşturduğu sonucuna varabiliriz. Böylelikle bu anlamların, anlatı üzerinden tanıtılmak istenen metalara yüklendiğini söyleyebiliriz.

Reklamcılar ürünleri anlamlandırabilmek için tanıtılan ürünü hedef kitle için anlam ifade eden bir nesneye dönüştürmeye çalışırlar. Ürün dönüşümü yaşadıktan sonra anlamın sembolü haline dönüşmüş ve ona ait tüm özellikleri kendine mal etmiştir (Bat1, 2010:257).

Batı'nın bu yorumundan yola çıkarak yüklenmek istenen anlamların, Roland Barthes'ın mit kavramı üzerinden işlediğini söyleyebiliriz. Reklam üzerinden işlenmiş olan anlam metayı sadece bir meta olmaktan çıarıp gösteren gösterilen ilişkisi üzerinden bir mitin göstereni haline dönüştürmektedir. Bu sayede bir metayı başka bir metadan statü ve kapitalist mit olarak diğerlerinden ayıran reklamlar tarafından o metaya yüklenen anlamdır. Bu dönüşüm insanların metayı tüketim amaçlarını da değiştirmektedir.

Uğur Batı (2010:250) Reklamın Dili isimli kitabında bu konuyu “Ürünlerin işlevlerinden çok, çağrışımları ve sahip oldukları anlamları için satın aldığımız bir ortam yaşıyoruz. Böylece yaşamımıza anlam katıyor geçerli bir kimlik ediniyoruz." Şeklinde yorumlamaktadır. Bu sistem içerisinde tüketicilere kendilerini ifade edebilecekleri bir araç sağlanmış olur.

Reklamlar tarafından postmodern tüketiciye verilen mesajlar o tüketicinin kendisini konumlandırmak istediği statüye ve kendisini ifade etmek istediği şekle hizmet eden bir referanstır. Bu referansa göre satın alınan ve kullanılan meta Lacan'ın belirtmiş olduğu insanların kendilerini semboller üzerinden ifade etmesini sağlayan bir semboldür. Bu durumun daha iyi anlaşılabilmesi için postmodern tüketim anlayışına değinilmesi gerekmektedir. 


\title{
POSTMODERN TÜKETIM
}

Postmodern tüketimden bahsedebilmek için öncelikle post-fordist üretim anlayışından bahsetmek gerekmektedir. Post-fordist üretim 1980'li yıllarda başlamış olan bir üretim biçimidir. Bu dönem arz-talep ilişkisinde talebin doyuma ulaşması ve kapitalist sistemin kendisine bir çözüm bulması sonucunda ortaya çıkmıştır (Dağtaş ve Dağtaş, 2006:12-13). Kapitalizmin karlılık konusundaki kilit mesele olan devir hızının üretimdeki yeni teknolojiler sayesinde artması ancak tüketimdeki devir hızının artmaması sonucu ortaya çıkan problem sistemin değişmesine neden olmuştur. Çözüm olarak, çabuk değişen moda ve bu konuya devamlı olarak dikkat çekilerek göz boyanmasına ihtiyaç duyulmuştur (Harvey, 2012:180). Kapitalizm "boş zaman" kavramınıda paraya çevirebilir bir kavram olarak ele almıştır. Bu noktada tüketimin bir yaşam biçimine dönüşmesi önem kazanarak kimlikler ön plana çıkarılmaya çalışılmıştır (Dağtaş ve Dağtaş, 2006:16-21).

Üretim üzerindeki bu değişim tüketim alışkanlıklarını da etkilemiştir. Daha önceleri sadece statü göstergesi olan mallar artık insanların yaşam tarzlarını da göstermektedirler. Bugün metalardan aldığımız zevk tüketmekle ancak kısmen ilişkilidir. Artık metalar hayati bir damga olarak tüketiciler tarafından kullanılmaktadır (Featherstone, 2013:46).

Debord'a (2012:39) göre :
"Iktisadın toplumsal yas,am üzerindeki tahakkümünün ilk as,aması, buitün insan gerçekleștirmelerinin tanımlanmasında, var olmaktan sahip olmaya geçen bariz bir bayağlaşmaya yol açmıștır. Toplumsal yașamın, iktisadın birikmis, sonuçları tarafından butünüyle isgal edildiğ bugünkü așama ise, sahip olmaktan 'gibi görünmeye dogru genel bir kaymaya neden olmus,tur"

Böylelikle bireyler sahip olmak istedikleri kimlikleri elde etmek için metaları tüketerek kendilerini kimliklere büründürme çabası içerisindedirler.

Robert Bocock'a (2009:86) göre :

\begin{abstract}
“Belli bir gurubun üyeleri arasındaki etnik kimlik duygusunun, benzer bir ekonomik sınıf pozisyonuna sahip olan diğerlerine karşı üretebileceği düşmanlık duygusu, sosyo-kültürel öğelerin bir gurubun davranışlarını nasıl etkileyebileceği ile ilgili ampirik bir örnek olarak görülebilir. Giyim stilleri, müzik zevkleri, boş zaman değerlendirme uğraşları, gıda ve içecek tüketimi gibi konularda etnik özellikler tüketim kalıplarını da etkileyebilir, çünkü tüketim kalıpları guruplar arasındaki farklılıkları vurgulamak veya sürdürmek amacıyla, etnik gruplar arasındaki sınırları çizmek, gruptakilerden bazılarını üye olarak belirleyip diğerlerini "dışlamak" için kullanılabilirler."
\end{abstract}

Bireyler seçebilecekleri modellerden istedikleri birisini seçerek ve onun tüm zorunlu techizatını satın alarak o modeli onaylayan bir gurubun üyesine dönüşebilirler. Gurubun 
üyesi olmak için sadece o guruba özgü ürünleri satın almak, o grubun zaman geçirdiği mekanlarda zaman geçirmek ve o grubun kültürel ürünlerini kullanmak yeterlidir (Bauman, 2013:228).

Kişiler semboller satın alarak katıldıkları kabileler tarafından denetlenmezler ancak bu işi bu kabileler yerine piyasa yapmaktadır. Kabileler özlerinde hayat tarzlarıdır ve hayat tarzları neredeyse tamamen tüketim tarzlarından başka birşey değildir. Tarzların tüketimini karşılayacak neredeyse her şey piyasada bulunmaktadır. Alınıp satılamayan (meta olmayan) mallar genellikle kabul edilebilir tarzların yapı taşları olarak görülmezler (Bauman, 2013:229).

Featherstone, Postmodernizm ve Tüketim Kültürü isimli kitabında Douglas ve Isherwood'un tüketim mallarını üç kategoriye ayırmasından bahsetmektedir. Bu kategoriler temel mallar (yiyecek), teknoloji dizisi (gezi ve tüketicinin sermaye donanımı), enformasyon dizisidir (enformasyon ürünleri, kültürel meşgaleler, boş zaman meşgaleleri). Toplumsal yapının en alt sınıfında bulunan kişiler sadece temel malların tüketimine ihtiyaç duyarken toplumun en üst kesimi enformasyon ürünlerine kadar hepsini tüketme ihtiyacı duymaktadırlar. Ayrıca enformasyon sınıfında yer alan ürünlerin tüketilmesi kendi içerisinde bir rekabet yaratmaktadır. Bu rekabette toplumsal açıdan dışlamak için yüksek engeller yaratmaktadır (Featherstone, 2013:46-47).

Featherstone a göre (2013:47) "Bizim tüketim pratiklerine ayırdığımız zaman sinıfsal alışkanlıklarımızı gösterir ve bundan dolayı sınıfsal statümüze ilişkin doğru bir fikir verir." Firmalar tarafından devamlı olarak üretilen yeni metalar ve moda yoluyla bunların desteklenmesi toplumu tüketime yöneltmektedir. Uygun ve arzu edilen malların alt gelir guruplarına sahip tüketiciler tarafından tüketilmeye çabalanması üst guruplar tarafından statü aralığının tekrar açma çabalarını doğurmaktadır. Böylelikle üst guruplar enformasyonel metalara yatırım yapmak zorunda kalırlar ve bu durum yakalamacaya dönüşmektedir (Featherstone, 2013:48).

Değişmeye ve moda takibine niyetli olan tüketiciler bu tüketim alışkanlıkları üzerinden toplumsal bir sınıflandırma ipucu dizisi oluştururlar. (Featherstone, 2013:50)

\section{SANAL BİR ORTAM OLARAK SOSYAL MEDYA}

Sosyal medya, daha önceleri sadece bir kaç medya kuruluşunun elinde bulunan tek yönlü iletişimin hakim olduğu iletişim modelini değiştirerek kullanıcıları da birer yayıncı haline getirmiştir (Kahraman, 2010:13-14).

Günümüz teknolojileri sayesinde daha önce geleneksel medya tarafından yaratılan sanal alanlar sosyal medya sayesinde bireyler tarafından da yaratılabilir hale gelecektir/gelmiştir. Kevin Robins (2013:40) İmaj isimli kitabında sanal alanın arzulanan ortamı sağlaması konusuna şu şekilde değinmiştir: "Sanal alanın çekici olmasının nedeni aslında uzak, dokunulmaz ve kurgusal bir yer olmasıdır. Arzularımızın ve düşlerimizin içinde daha rahat edeceği alternatif bir dünya olarak görülmektedir." 
$\mathrm{Bu}$ alan içerisinde kişilerin kendileri için yarattıkları gerçekliğin hüsrana uğraması olanaksızdır (Robins,2013:41). Buradan yola çıkarak sanal ortamlar içerisinde ütopyalarını yaratabilen insanların kenilerini de bu ortamlar içerisinde istedikleri gibi yaratabileceklerini söyleyebiliriz.

\section{YÖNTEM}

İnstagram gibi metin üzerinden yapılabilecek araştırmalarda niteliksel araştırma yöntemleri katılımcıların konu hakkındaki düşünce ve davranışlarını daha görünür kılmaktadır. Kaynak üzerinde yapılan araştırmada derinlemesine görüşme kullanılarak bu görüşmelerdeki bulgular fenomenolojik olarak incelenmiştir.

Fenomenoloji, farkında olduğumuz ancak derinlemesine ve ayrıntılı bir anlayışa sahip olmadığımız fenomenlere odaklanmaktadır (Yıldırım ve Şimşek, 2013:78). Bu sebeple çalışma içerisinde derinlemesine görüşmenin analizinde fenomenolojik yöntemin kullanılması uygun görülmüştür.

\section{SINIRLILIKLAR VE ÖRNEKLEM}

Tüik'e göre internet en çok 16-24 yaş arasında kullanılmaktadır (http://www.tuik.gov.tr/PreIstatistikTablo.do?istab_id=2599). Webrazzi'nin verilerine göre Sosyal Medya en çok gençler arasında kullanılmaktadır (https://webrazzi.com/2014/04/19/ turkiyede-cinsiyet-yas-ve-mezun-olunan-okula-gore-sosyal-medya-kullanimi-webrazzi-

pro/). Bu çalışmada 18-24 yaş arası üniversite öğrencileri ile araştırma yapılacaktır. Çalışmada verilerin toplanabilmesi için Kocaeli Üniversitesi İletişim Fakültesi seçilmiştir. Buradaki öğrencilere öncelikle instagram kullanıp kullanmadıkları sorulmuş daha sonra akademik bir araştırmaya katılımcı olmak isteyip istemedikleri sorulmuştur. Görüşme yarı yapılandırılmış ve görüşme boyunca sorulmuş sorular ile sınırlandırılmıştır.

Fenomenolojik araştırmalarda veri kaynakları araştırma konusundaki fenomeni yaşamış ve bu algıyı anlatabilecek kişi ya da gruplardan oluşmaktadır. (Yıldırım ve Şimşek, 2013:80) Katılımcıların tecrübeleri ve konu hakkındaki bakış açılarının anlaşılabilmesi için her katılımcı ile derinlemesine görüşme yapılmıştır.

\section{VERILLERIN TOPLANMASI VE ANALIZII}

Fenomenolojik araştırmalarda başlıca veri toplama aracı görüşmedir. (Yıldırm ve Şimşek, 2013:80) Araştırmada yarı yapılandırılmış görüşme yapılmasının sebebi budur. Değerlendirme sonucunda katılımcıların cevapları tablolar halinde bulgular bölümünde verilmiş ve değerlendirilmiştir. Katılımcı olan kişilerin kimliklerinin gizli tutulması için "A Kişisi" , "B Kişisi" ve "C Kişisi" gibi isimler verilmiştir. Katılımcılar arasında A Kişisi, B kişisi, C kişisi ve D kişisi kadındır. E Kişisi, F Kişisi, G kişisi ve H kişisi erkektir.

\section{BULGULAR}

Yapılmış olan araştırma sonucunda kişiler ile yapılmış olan görüşmede elde edilen sonuçlar ve yorumları aşağıda verilmiştir. 
AJIT-e: Online Academic Journal of Information Technology

2018- Informatics and Communication Technologies Special Issue/iletişim ve Bilişim Teknolojileri

Özel Sayı -Cilt/Vol: 9-Sayı/Num: 35

DOI: 10.5824/1309-1581.2018.5.006.x

Tablo 1: Katılımcilar

\begin{tabular}{|l|l|}
\hline Soru 1 & Biraz kendinizden bahseder misiniz? (Okul, Yaş, Ne iş yapmaktasınız vb.) \\
\hline A Kişisi & 19 yaşındayım Halkla ilişkiler bölümü 1. Sınıf Öğrencisiyim. \\
\hline B Kişisi & Kocaeli Üniversitesinde okuyorum. 18 yaşındayım. Öğrenciyim. \\
\hline C Kişisi & Kocaeli Üniversitesinde okuyorum. Gazetecilik bölümü. 18 yaşındayım. \\
\hline D Kişisi & $\begin{array}{l}\text { 19 yaşındayım. Bu sene üniversiteye başladım. Kendime sürekli hobi edinmeye } \\
\text { çalışıyorum. Sulu boya olsun, penç nakış olsun. Evde yapabileceğim şeyler } \\
\text { daha çok. Kitap okumayı seviyorum. Çok fazla dışarı çımıorum öyle. }\end{array}$ \\
\hline E Kişisi & $\begin{array}{l}\text { 23 yaşındayım aynı zamanda ticaret olarak bir dükkanım var orasıla } \\
\text { uğraşıyorum. Kocaeli Üniversitesine Fırat üniversitesinden geldim. Yatay geçiş } \\
\text { olarak. Kurumlar arası başarı ile geldim. Bu sene son sınıfım. Onun dışında } \\
\text { okulla ilgileniyorum bir de işimle ilgileniyorum. }\end{array}$ \\
\hline F Kişisi & $\begin{array}{l}\text { 98 doğumluyum 20 yaşına yeni girdim. Gümüşhane Üniversitesinde 1. Sınıfı } \\
\text { tamamlamıştım. Yatay geçişle Kocaeli Üniversitesine geldim. Şu an } \\
\text { buradayım, okulu tanımaya çalışıorum açıkçası. }\end{array}$ \\
\hline G Kişisi & $\begin{array}{l}\text { 20 yaşındayım. Öğrenciyim. Kocaeli Üniversitesi 2. Sınıf radyo televizyon } \\
\text { sinema öğrencisiyim. }\end{array}$ \\
\hline H Kişisi & $\begin{array}{l}\text { Radyo televizyon 4. Sınıf öğrencisiyim. İki sene Kastamonu Üniversitesinde } \\
\text { okumuştum. Daha sonra yatay geçişle buraya geldim. Ara ara çalışıyorum. 22 } \\
\text { yaşındayım. }\end{array}$ \\
\hline
\end{tabular}

Tablo 1'e baktığımızda katılımcıların yaşıt olduklarını söyleyebiliriz.

Tablo 2: Sosyal medya kullanımına başlama dönemi

\begin{tabular}{|l|l|}
\hline Soru 2 & Sosyal medya kullanmaya neden ve ne zaman başladınız? \\
\hline A Kişisi & $\begin{array}{l}\text { Tahminen 9-10 yaşlarında başladım. Herkes kullanıyordu. Ben de böyle bir } \\
\text { giriş yaptım. Başta Facebook vardı. Sonra dahil olduk; herkes onu indiriyordu } \\
\text { falan. }\end{array}$ \\
\hline B Kişisi & 6 yıl önce başladım. Nedeni yok. \\
\hline C Kişisi & Dört yıl önce başladım. Vakit geçirmek için. \\
\hline D Kişisi & $\begin{array}{l}\text { Ben aslında küçük yaşta başladım çünkü hep abilerimiz ablalarımız o } \\
\text { zamanlarda Facebook, MSN falan kullanıyorlardı. Biz de merak edip hesap } \\
\text { açıyorduk. Bu şekilde başladı. }\end{array}$ \\
\hline E Kişisi & $\begin{array}{l}\text { Çok küçükken başladım yani yanılmıyorsam 2008'den bu yana kullanıyorum. } \\
\text { Çünkü artık çağımız nasıl desem mektuptan telefon SMS'ine, SMS'ten } \\
\text { elektronik postadan sosyal ağa doğru ilerlediği için insanlar zaten bunun } \\
\text { içerisinde adapte oldu. Birbirleriyle iletişimle ya da nasıl desem zaman geçirme } \\
\text { amaçlı eğlence potansiyeli olan bir aktivite yaratmak için kendilerine bu sosyal } \\
\text { ağları tercih etti ben de bu yüzden dahil oldum. }\end{array}$ \\
\hline F Kişisi & $\begin{array}{l}\text { Yaklaşı lise 1'e yeni başladığımda falan başladım. Gerçi arkadaşlarım 7. 8. } \\
\text { Sinıfta başlamıştı ama ben böyle açıkçası çok bakmıordum. Sonra } \\
\text { arkadaşlarım Facebooku tanımaya başladılar. Beni de çağırdılar gel fotoğraf } \\
\text { atalım bir şeyler yapalım diye. Öyle başladım. Başta fotoğraf amaçlı }\end{array}$ \\
\hline
\end{tabular}




\begin{tabular}{|l|l|}
\hline & $\begin{array}{l}\text { takılıyordum. Sonradan oyun eklenince daha da iyi oldu. Instagramla tanışmaya } \\
\text { başladım sonradan daha çok haberleri falan takip ediyorum televizyon hiç } \\
\text { izlemiyorum artık. }\end{array}$ \\
\hline G Kişisi & $\begin{array}{l}\text { Yaklaşık 2014 yılında başladım. Etkileşim için arkadaşlarla birşeyleri } \\
\text { paylaşmak ve sohbet için... }\end{array}$ \\
\hline H Kişisi & $\begin{array}{l}\text { İlk çıktığından beri kullanıyorum çünkü hayatımıza tamamıyla girdi. Orta son } \\
\text { 7. Sınıfta ilk Facebooku açtım. Vakit geçirmek için gündemden haberdar olmak } \\
\text { ççin. }\end{array}$ \\
\hline
\end{tabular}

Tablo 2'ye baktığımızda A, D, E, F ve H kişileri sosyal medya kullanmaya erken başlamış ve $\mathrm{B}, \mathrm{C}$ ve $\mathrm{G}$ kişileri sosyal medyayı günümüze daha yakın bir zamanda kullanmaya başlamışlardır.

Tablo 3: Sosyal medya neyi ifade ediyor

\begin{tabular}{|c|c|}
\hline Soru 3 & Sosyal medya size neyi ifade ediyor? \\
\hline A Kişisi & $\begin{array}{l}\text { Bana paylaşımı ifade ediyor. Bir şeyleri aktarmayı. İnsanları takip etmeyi nasıl } \\
\text { diyeyim anlık şeyleri görmeyi yani insanlarla paylaşmayı. }\end{array}$ \\
\hline B Kişisi & Eğlence, zaman harcamak \\
\hline C Kişisi & Boş zamanlarını doldurmak. \\
\hline D Kişisi & $\begin{array}{l}\text { Sosyal medya bir yandan çok fazla bilgi kirliliği olan ve zaman kaybı gibi olan } \\
\text { bir şey; bir yandan da her istediğimizi düşüncelerimizi başkalarıyla } \\
\text { paylaşabileceğimiz özgür bir alan. İyisiyle kötüsüyle var. }\end{array}$ \\
\hline E Kişisi & $\begin{array}{l}\text { Sosyal medya insanların kendini kısıtlamadan kendi evi veya dışarıda olmak } \\
\text { üzere paylaşımlarını birbirlerine aktardıkları bir ortam. Birlikte geçirdikleri } \\
\text { zaman diliminin sosyal ağlar üzerinden etkileşimini sağlıyor. Aynı zamanda } \\
\text { birbirleriyle de haberleşmeyi sağlayan çeşitli bir ağ olduğu için tek bir şeyi } \\
\text { ifade etmiyor. Benim için birkaç şeyi ifade ediyor. }\end{array}$ \\
\hline F Kişisi & Haber, eğlence, içerikler her şeyi ifade ediyor. \\
\hline G Kişisi & $\begin{array}{l}\text { Bana insanların birbirleriyle etkileşimini ifade ediyor. İç ses gibi bir şeydir. } \\
\text { Bazı insanlar bazı şeyleri söylemek istemez sessiz söylemek ister. Bu da iç ses } \\
\text { gibi arkadaşınla etkileşime geçebileceğimiz bir ortam. }\end{array}$ \\
\hline H Kişisi & $\begin{array}{l}\text { Günlük ne yaptıysak ona atıyoruz. Güncel yaşamımızla bir. Nerdeyiz ne } \\
\text { yapmaktayız onu anlatmak için kullanıyoruz ya da insanların ne yaptığını } \\
\text { görmek için. }\end{array}$ \\
\hline
\end{tabular}

Tablo 3'e baktı̆̆ımızada katılımcılar için sosyal medya eğlence, boş zaman geçirme, etkileşim, paylaşım ve kendini ifade etme aracı olduğunu söyleyebiliriz.

Tablo 4: En çok kullanılan sosyal medya uygulamaları

\begin{tabular}{|l|l|}
\hline Soru 4 & En çok hangi sosyal medya uygulamalarını kullanıyorsunuz? \\
\hline A Kişisi & Intagram en çok. Twitter, Facebook en sonda geliyor. \\
\hline B Kişisi & Instagram ve Whatsapp \\
\hline C Kişisi & Instagram ve Whatsapp \\
\hline D Kişisi & $\begin{array}{l}\text { Sadece instagramı kullanıyorum. Diğerlerinde de hesaplarım var ama aktif } \\
\text { olarak kullanmıyorum. }\end{array}$ \\
\hline E Kişisi & Önceden facebook kullanıyordum. Şu an devir döndü Instagram kullanıyorum. \\
\hline F Kişisi & Instagram ve Youtube. Facebook artık 2. Planda kaldı benim için. \\
\hline
\end{tabular}


AJIT-e: Online Academic Journal of Information Technology

2018- Informatics and Communication Technologies Special Issue/iletişim ve Bilişim Teknolojileri

Özel Sayı -Cilt/Vol: 9-Sayı/Num: 35

DOI: 10.5824/1309-1581.2018.5.006.x

\begin{tabular}{|l|l|}
\hline G Kişisi & Günümüzün en popüler olanı Instagram. \\
\hline H Kişisi & $\begin{array}{l}\text { Bir tek Instagram kullanıyorum. Ara ara Snapchat kullandım. O da bitti tabii. } \\
\text { Şu an tek kullandığım Instagram. }\end{array}$ \\
\hline
\end{tabular}

Tablo 4'e baktığımızda bütün kullanıcılar en çok Instagramı kullanmaktalar. B ve C kişisi Whatsappı da kullanmakta. A, E ve F kişileri Facebook'un artık ikinci planda olduğunu belirtmekteler. H kişisi ise önceden Snapchat kullandığını ama artık kullanmadığını belirtmekte.

Tablo 5: Sevilen uygulamaların neden sevildiği

\begin{tabular}{|c|c|}
\hline Soru 5 & Sevdiğiniz sosyal medya uygulamarını neden sevdiğinizi açıklar mısınız? \\
\hline A Kişisi & $\begin{array}{l}\text { Instagrama story kısmı geldiği için anlık şeyleri paylaşmayı daha çok } \\
\text { seviyorum. Bir sürü yabancı falan takip ediyorum onların yaptığı şeyleri } \\
\text { görmek için. Bu yüzden seviyorum. }\end{array}$ \\
\hline B Kişisi & $\begin{array}{l}\text { Instagramı seviyorum daha çok çünkü keşfette daha çok çeşitli şeyler } \\
\text { görüyorum ve ilgimi çekiyor. }\end{array}$ \\
\hline C Kişisi & Arkadaşlarımla iletișim kurmak daha kolay oluyor. \\
\hline D Kişisi & $\begin{array}{l}\text { Instagramı seviyorum çünkü oradan kendi ilgi alanlarımla ilgili bir sürü hesap } \\
\text { bulup bilgi alabiliyorum. Pinterest gibi. }\end{array}$ \\
\hline E Kişisi & $\begin{array}{l}\text { En azından elimin altında hazır. Hazır olduğu için de çabuk tüketiliyor. Çabuk } \\
\text { tüketildiği için de tercih ediliyor. }\end{array}$ \\
\hline F Kişisi & $\begin{array}{l}\text { Instagram'da her türlü içerik bulabiliyorsun mesela eğlence içerikleri, oyun } \\
\text { içerikleri. Youtube'ta da mesela çoğu oyun videoları falan izliyorum ben belli } \\
\text { başlı takip ettiğim kanallar var. }\end{array}$ \\
\hline G Kişisi & Instagram fazla yazılarla değil de görsellikle ön planda. \\
\hline H Kişisi & $\begin{array}{l}\text { Instagramı seviyorum çünkü hem vakit geçirebileceğin videolar var hem de } \\
\text { paylaşıyorsun. Gittiğin yerleri, gördüğün yerleri. Seni görüyorlar. Sen diğer } \\
\text { arkadaşlarının ne yaptığını görebiliyorsun. }\end{array}$ \\
\hline
\end{tabular}

Tablo 5'e baktığımızda B, D ve F kişileri yeni içerikler keşfedebildikleri için Instagramı sevmekte. A ve H kişileri Instagramı paylaşım yapabildikleri için sevdiklerini belirtmekte. E kişisi instagramı çabuk tüketildiği için tercih ettiğini belirtiyor. G kişisi instagramı görselliğin ön planda olduğu için sevdiğini belirtmekte. F kişisi Instagram dişında başka bir uygulamadan söz eden tek katılımcı olmakla birlikte o da Youtube uygulamasını oyun videosu izlemek ve belli başlı kanalları takip etmek için kullanmakta.

Tablo 6: Instagram nasıl kullanılıyor?

\begin{tabular}{|l|l|}
\hline Soru 6 & Instagramı nasıl kullanıyorsunuz? \\
\hline A Kişisi & Fotoğraf atarak. \\
\hline B Kişisi & Bir şeyleri öğrenmek için bakıyorum. Değişik pratik bilgiler ilgimi çekiyor. \\
\hline C Kişisi & $\begin{array}{l}\text { Genelde keşfetten yeni şeylere bakarak videolar izleyerek yeni bilgiler } \\
\text { ŏğrenerek. }\end{array}$ \\
\hline D Kişisi & $\begin{array}{l}\text { Instagramı hem insanları takip etmek için kullanıyorum tanıdıklarımı hem de } \\
\text { hobilerini paylaşan insanları takip etmek için kullanıorum. }\end{array}$ \\
\hline E Kişisi & $\begin{array}{l}\text { Instagramı işte olduğum zaman aktif olarak kullanmıyorum. Ancak işim } \\
\text { olmadığı zamanda izin günlerimde aktif olarak kullanıyorum. Fotoğraf }\end{array}$ \\
\hline
\end{tabular}




\begin{tabular}{|l|l|}
\hline & $\begin{array}{l}\text { yüklediğim zaman arakadaşlarımın fotoğraflarına bakıyorum zaman geçiyor. } \\
\text { Eğlenceli bir şey aslında ama o kadar da kaptırılmaması gerektiğini } \\
\text { düşünüyorum. }\end{array}$ \\
\hline F Kişisi & $\begin{array}{l}\text { Bazen içeriklere, mesajlara, komik capslere bakmak için girerim. Bazen } \\
\text { mesajlaşıyorum. Bazı arkadaşların içeriklerini fotoğraflarını görüyorum. Öyle } \\
\text { yani. }\end{array}$ \\
\hline G Kişisi & $\begin{array}{l}\text { Instagramı genellikle önemli paylaşımları yapmak için kullanıyorum. } \\
\text { Arkadaşlara ve benzeri aile gurubuna, akraba grubuna göstermek için yani bazı } \\
\text { şeyleri daha ön plana çıkarmak için. }\end{array}$ \\
\hline H Kişisi & $\begin{array}{l}\text { Çok etkin bir şekilde kullanmıorum. Sadece normal vakit geçirici. Bazen } \\
\text { paylaşımlar yapıyorum. Aşırı sürekli paylaşımlar yapan bir insan da değilim. }\end{array}$ \\
\hline
\end{tabular}

Tablo 6 ya baktığımızda kullanıcılar instagramı birşeyleri öğrenmek, zaman geçirmek ve önemli paylaşımlarda bulunmak gibi pek çok amaçla kullanıyorlar.

Tablo 7: Instagram paylaşımlarında dikkat edilenler

\begin{tabular}{|l|l|}
\hline Soru 7 & Instagramda bir paylaşım yaparken nelere dikkat ediyorsunuz? \\
\hline A Kişisi & $\begin{array}{l}\text { Tabii ki nasıl çıtığım öncelik olarak. Nerede olduğum. Neyi paylaşacağıma } \\
\text { göre değişiyor. }\end{array}$ \\
\hline B Kişisi & Paylaşacağım şeyin güzelliğini ve ne kadar beğeni alacağını düşünüyorum. \\
\hline C Kişisi & Bulunduğum ortama. \\
\hline D Kişisi & $\begin{array}{l}\text { Kendimle ilgili olmasına dikkat ediyorum. Etrafı çekmek yerine kendimi ve } \\
\text { sevdiklerimi göstermesini. }\end{array}$ \\
\hline E Kişisi & $\begin{array}{l}\text { Okulda zaten bize bunu öğrettiler. Fotoğrafın enine boyuna çerçevesine kadar } \\
\text { dikkat ediyorsun. Dikkat ettiğin zaman da bu sana bir haz veriyor. Paylaştığın } \\
\text { zaman da bir beklentiye giriyorsun. }\end{array}$ \\
\hline F Kişisi & $\begin{array}{l}\text { Ben bazen abuk subuk şeyler paylaşırım. Görülmesini istemediğim kişiler } \\
\text { olursa direkt kapatıyorum o düzenlemeden. Bazen de konum atmaya dikkat } \\
\text { ediyorum. Etiketlemeye dikkat ediyorum o tarz şeyler. }\end{array}$ \\
\hline G Kişisi & $\begin{array}{l}\text { Genellikle görsel paylaştığım için estetiğe dikkat ediyorum. Tabii vereceği } \\
\text { anlama, derin anlama ve benzeri. }\end{array}$ \\
\hline H Kişisi & $\begin{array}{l}\text { Çok dikkat ettiğim birşey yok. Normal içimden ne geliyorsa. Fotoğraf } \\
\text { atıyorsam altına yorum atıyorum. Bazen atmıorum. Çok da bir şey atmıorum. } \\
\text { Güzel bir fotoğraf çekiyorum o an atıyorum ya da o an mutluyumdur } \\
\text { çekiliyorumdur atıyorumdur. Sürekli atan bir insan değilim. }\end{array}$ \\
\hline
\end{tabular}

Tablo 7 ye baktığımızda katılımcılardan A ve C kişileri bulundukları ortama dikkat etmekte. B, E ve G kişileri estetik bir görünüm olmasına dikkat etmektedirler. B kişisi fotoğrafı paylaştığında ne kadar beğeni alacağını düşünürken E kişisi de paylaşım yaptıktan sonra bir beklenti içerisine girdiğini ifade etmekte. F kişisi bazı paylaşımlarında kişileri engellemekte olduğunu belirtiyor. A ve D kişileri kendisi ile ilgili şeylere dikkat etmekte.

\section{Tablo 8: Instagramda paylaşılacak fotoğrafta dikkat edilenler}

\begin{tabular}{|l|l|}
\hline Soru 8 & Instagramda paylaşmak için çektiğiniz bir fotoğrafta nelere dikkat ediyorsunuz? \\
\hline A Kişisi & $\begin{array}{l}\text { Mesela bir manzara çekiyorsam o manzarayı almaya özen gösteririm ya da } \\
\text { kendimi çekiyorsam arkada çıan şeye dikkat ederim. }\end{array}$ \\
\hline B Kişisi & Yüzüme. Kısaca fotoğrafin güzelliğine. \\
\hline
\end{tabular}


AJIT-e: Online Academic Journal of Information Technology

2018- Informatics and Communication Technologies Special Issue/iletişim ve Bilişim Teknolojileri

Özel Sayı -Cilt/Vol: 9-Sayı/Num: 35

DOI: 10.5824/1309-1581.2018.5.006.x

\begin{tabular}{|l|l|}
\hline C Kişisi & Fark etmiyor. Şu an düşündüm ama hiçbir şey gelmedi aklıma. \\
\hline D Kişisi & $\begin{array}{l}\text { Fotoğrafın canlı görünmesi. Görüldüğ̈ zaman canlı ve sıcak bir his } \\
\text { uyandırması. }\end{array}$ \\
\hline E Kişisi & $\begin{array}{l}\text { Genel anlamda yine saydığım oranlara altın orana, güzel gözüktüğüme dikkat } \\
\text { ediyorum. Onun dışında pek fazla dikkat etmiyorum. }\end{array}$ \\
\hline F Kişisi & $\begin{array}{l}\text { Genelde alıntı yazmaya dikkat ediyorum. S.S. (screen shot) almışsam mesela } \\
\text { etrafını dikkat ederek kesip altına da alıntı diye ekliyorum mesela. }\end{array}$ \\
\hline G Kişisi & $\begin{array}{l}\text { Genellikle güzel görünmek. Instagram'ı ben ve benim gibi kullanan kişiler } \\
\text { güzel görünmek, güzel anlam ifade eden şeyler paylaşmak ister. }\end{array}$ \\
\hline H Kişisi & $\begin{array}{l}\text { Dişarıdan bakıldığı zaman absürt gözükmemesine dikkat ederim. Normal } \\
\text { yaşıma uygun. Fotoğrafın güzelliği ya da benim güzel çıkmam. Altın orana da } \\
\text { dikkat ederiz tabii. }\end{array}$ \\
\hline
\end{tabular}

Tablo 8 e baktığımızda A kişisi fotoğraf içerisindeki öğelere dikkat etmekte. B, G, H kişileri kendisinin ve fotoğrafın güzel gözükmesine özen göstermektedir. D kişisi için fotoğrafın canlı gözükmesi önemlidir. F kişisi alıntı olduğunu belirtme konusunda özen göstermekte. C kişisi için farketmiyor.

Tablo 9: Instagramda Rötuş programları kullanılıyor mu?

\begin{tabular}{|l|l|}
\hline Soru 9 & $\begin{array}{l}\text { Çekmiş olduğunuz fotoğrafları paylaşmadan önce Photoshop tarzı programlarla } \\
\text { rötuşluyor musunuz? Evet ise neden? }\end{array}$ \\
\hline A Kişisi & $\begin{array}{l}\text { Ya şöyle yapıyorum ama kendi üzerimde bir şey yapmıyorum. Mesela etrafı } \\
\text { kapatmak ççin. Mesela bizim burada bir kafe var ya onun bir duvarı var. O } \\
\text { duvar çok kötüydü klima falan çıkıyordu. Duvara baya taş dizdim mesela ama } \\
\text { kendimi hiç ellemedim sadece orayı böyle farklı bir manzara gibi paylaşmıştım. } \\
\text { Sirf bu yüzden kullanıyorum. }\end{array}$ \\
\hline B Kişisi & Rötuşlamıyorum. \\
\hline C Kişisi & Hayır \\
\hline D Kişisi & $\begin{array}{l}\text { Rötuşlamıorum ama efektleri kullanıyorum çünkü fotoğraf olduğu halden } \\
\text { daha göze çarpıcı hale geliyor. Diğer fotoğraflar arasından seçilebilir oluyor. }\end{array}$ \\
\hline E Kişisi & Rötuşlamıyorum zaten telefondan olduğu gibi çekip aktarıyorum. \\
\hline F Kişisi & $\begin{array}{l}\text { Yok o tarz onlara gitmedim. Gitmeyi de düşünmüyorum çünkü o tarz şeyler } \\
\text { çalıntı diye biliyorum. }\end{array}$ \\
\hline G Kişisi & $\begin{array}{l}\text { Genel olarak kullanıyorum. Bazen istemsiz geniş açı oluyor. Geniş açıyı } \\
\text { kısıtlamak için arkalara flu, renk ve ton ayarları yapıorum. }\end{array}$ \\
\hline H Kişisi & Bazen. Kesmek oluyor arada bir de efekt. Hoş gözüksün diye. \\
\hline
\end{tabular}

Tablo 9' a baktığımızda D ve H kişileri efektleri kullanmaktadır. A,G ve H kişileri fotoğrafta beğenmedikleri şeyleri düzeltmek için şekil kullanıyorlar. B, C, D, E, F Kişileri rötuşlama kullanmiyorlar. 
Tablo 10: Instagramda paylaşım kaldırılması

\begin{tabular}{|l|l|}
\hline Soru 10 & Instagramdan paylaşımlarınızı kaldırıyor musunuz? Evet ise sebepleri nelerdir? \\
\hline A Kişisi & Paylaşımlarımı kaldırmıyorum. \\
\hline B Kişisi & Bazılarını kaldırıyorum çünkü beğenisi düşük olursa hoşuma gitmiyor. \\
\hline C Kişisi & Kaldırmıyorum. \\
\hline D Kişisi & $\begin{array}{l}\text { Kaldırıyorum çünkü sonradan gözüme hitap etmeyebiliyor. Önceden sevdiğim } \\
\text { bir şey oluyor. Sonradan hoşlanmadığım bir şey oluyor. Onu görmek } \\
\text { istemiyorum orada. }\end{array}$ \\
\hline E Kişisi & $\begin{array}{l}\text { Bu zamana kadar kaldırmadım ama yorum silmişliğim var. Hoş bazen mesela } \\
\text { bağdaşmayan yorumlar olabiliyor. O da şundan kaynaklanıor. O resmi } \\
\text { anlayabilmek için akademik bir şekilde bakmak gerekiyor. Anlamadığı için de } \\
\text { o yorumun gereksiz olduğunu düşünerek kaldırıyorum. }\end{array}$ \\
\hline F Kişisi & $\begin{array}{l}\text { Kaldırıyorum bazen bazı arkadaşlarımın görmesini istemiyorum ya da ne } \\
\text { bileyim bazı türlerin mesela ailemin görmesini istemiyorum. }\end{array}$ \\
\hline G Kişisi & $\begin{array}{l}\text { Zaten güzel olmayan şeyi paylaşmadığım için kaldırmıyorum. Kaldırsam da } \\
\text { veriye kaydolduğu için önemsemiyorum. }\end{array}$ \\
\hline H Kişisi & $\begin{array}{l}\text { Yok şu ana kadar kaldırmadım ama geçmişle ilgili bir şey ise kaldırırım. Kız } \\
\text { arkadaşımdan ayrılsam kaldırırım tabii ki. Şu ana kadar bir şey yok ama } \\
\text { ayrılsak kaldırırdım. }\end{array}$ \\
\hline
\end{tabular}

Tablo 10' a baktığımızda A, C, E, G ve H kişileri paylaşımlarını kaldırmamakta. B kişisi beğenisi düşük olan fotoğrafları kaldırıyor. D kişisi sonradan gözüne hitap etmediği için fotoğrafını kaldırıyor. F kişisi de bazı kişilerin görmesini istemediği fotoğrafları kaldırıyor.

Tablo 11: Like'ın anlamı

\begin{tabular}{|l|l|}
\hline Soru 11 & Instagramda beğeni "Like" almak size ne ifade ediyor? \\
\hline A Kişisi & $\begin{array}{l}\text { Açıçası nedensiz bir şekilde mutlu oluyorum. Bir şey ifade etmiyor. Sadece } \\
\text { paylaşıyorum insanlar ne kadar beğenecek diye takip ediyorum. }\end{array}$ \\
\hline B Kişisi & Bilmiyorum sadece hoşuma gidiyor. \\
\hline C Kişisi & Demek ki onların dikkatini çeken bir şey olduğunu ifade ediyor. \\
\hline D Kişisi & Hiçbir şey. \\
\hline E Kişisi & $\begin{array}{l}\text { Sevildiğimi bana saygı gösterdiklerini düşünüyorum. Takipçilerin de senin } \\
\text { arkadaşların üniversiteden tanıştığın kişiler. Bunlar da sana saygı duyuyor ya da } \\
\text { seviklerinden yaptıklarını düşünüyorum. Bana bunu ifade ediyor. }\end{array}$ \\
\hline F Kişisi & $\begin{array}{l}\text { Nasıı söyleyeyim havalı gözüküyor. Çok fazla dikkat etmedim ama takipçiye } \\
\text { dikkat ederim takipçim mesela az. Takipçi kasmak arada öyle şeylere } \\
\text { başvuruyorum. Gerçi onları da zamanla siliyorum ama böyle havalı gözükmek } \\
\text { için yapıyorum. }\end{array}$ \\
\hline G Kişisi & $\begin{array}{l}\text { Beğenilmek güzel bir duygu. Genel olarak benim Instagram takipçilerim ailem } \\
\text { olunca ailemin beğenmesi güzel bir anlam ifade ediyor. }\end{array}$ \\
\hline H Kişisi & $\begin{array}{l}\text { İnsanın hoşuna gidiyor. Kandırmayalım. Ahım şahım bir şey değil tabii ki ama } \\
\text { beğenisinin fazla olması insanın hoşuna gidiyor. }\end{array}$ \\
\hline
\end{tabular}

Tablo 11'e göre beğeni aldıkları zaman A, B, E, G, H kişileri mutlu oluyor ve hoşlarına gidiyor. A ve D kişileri için hiçbir şey ifade etmiyor ancak A kişisi paylaşımından sonra kaç beğeni alacağını takip ettiğini belirtmekte. C kişisi "dikkat çektiğini" anladığını ifade ediyor. F kişisi havalı gözüktüğünü ifade ediyor. 
AJIT-e: Online Academic Journal of Information Technology

2018- Informatics and Communication Technologies Special Issue/iletişim ve Bilişim Teknolojileri

Özel Sayı -Cilt/Vol: 9-Sayı/Num: 35

DOI: 10.5824/1309-1581.2018.5.006.x

Tablo 12: Konum Bildirimi yapma nedenleri

\begin{tabular}{|c|c|}
\hline Soru 12 & Instagramda paylaşımlarınızda hangi durumlarda konumunuzu belirtiyorsunuz? \\
\hline A Kişisi & $\begin{array}{l}\text { Gittiğim yer benim için çok özelse ancak o zaman. Her zaman gittiğim yerlerde } \\
\text { konum kullanmiyorum. }\end{array}$ \\
\hline B Kişisi & $\begin{array}{l}\text { Şehir dışında bir yerde olursam. Arkadaşlarım nerelere gittiğimi görsün belki } \\
\text { ileride beraber de gideriz diye. }\end{array}$ \\
\hline C Kişisi & Şehir dışında olduğumda. Çünkü yeni bir yere gittiğimi onlara göstermek için. \\
\hline D Kişisi & $\begin{array}{l}\text { Konum bildirimini çok fazla kullanmıyorum açıkçası. Kullanmadığım bir } \\
\text { özellik. }\end{array}$ \\
\hline E Kişisi & $\begin{array}{l}\text { Özel durumlarda konum bildirimi yapıyorum. Mesela tatil yörelerine gittiğimde } \\
\text { hoşuma gidiyor tabii ki de. O zaman konum bildirimi yapıyorum. Herkesin } \\
\text { hayatı boyunca gidemediği yerlerde konum bildirimi yapıyorum. Örneğin } \\
\text { Kelebekler Vadisi. Örnek veriyorum Türktelekom Stadyumu. }\end{array}$ \\
\hline F Kişisi & $\begin{array}{l}\text { Özel yerlere gittiğimde. İki hafta önce İstanbul'daydım. Özel yerlere gittim. } \\
\text { Galata Kulesi'ne falan konum attım mesela. O tarz şeylerde konum atarım ama } \\
\text { sıradan şeylerde konum atmam. }\end{array}$ \\
\hline G Kişisi & $\begin{array}{l}\text { Genellikle özel yere gittiğim zaman. Mesela Kiz Kulesi, Galata Kulesi. } \\
\text { İnsanlara bilindik yerler ya da görmedikleri yerlerin konumunu bildiriyorum } \\
\text { belki beğenir de gelmek ister diye. }\end{array}$ \\
\hline H Kişisi & $\begin{array}{l}\text { İlk defa gittiğim yerlerde yapıyorum. İstanbul'da bir yere gitmişimdir mesela } \\
\text { ya da Bursa'da vesaire tarihi bir yer olur. Önemli bir yerse atıyorum. Her yerde } \\
\text { konum yapmıyorum açkçası. Her gittiğim kafede veya İzmit'te yapmıyorum. } \\
\text { Önemli bir yerse. }\end{array}$ \\
\hline
\end{tabular}

Tablo 12' ye göre A, E, F, G, H kişileri kendileri için özel ve önemli bir yere gittiklerinde konum bildirimi yapmaktalar. $\mathrm{B}$ ve $\mathrm{C}$ kişileri şehir dışına çıktıklarında konum bildirimi yapmakta. D kişisi için konum bildirimi kullandığı bir özellik değil. A, F ve H kişileri her zaman gittikleri yerlerde konum bildirimi yapmadıklarını belirtmektedir.

Tablo 13: Instagramda kullanıcılara göre insanlar kendilerini yansıtıyor mu?

\begin{tabular}{|l|l|}
\hline Soru 13 & $\begin{array}{l}\text { Instagramda insanların kendilerini yansıttığını düşünüyor musnuz? Cevabınızın } \\
\text { nedenini açıklayınız. }\end{array}$ \\
\hline A Kişisi & $\begin{array}{l}\text { Hayır. Çünkü olabildiğimizin en iyisi olup birş eyler paylaşıyoruz. Mesela kimse } \\
\text { makyajsı bir şeyler paylaşmıyor ya da erkekler mesela saçına fön çekmeden } \\
\text { birşey koymuyor. Şu masayı bile çekeceksek düzenleyip çekiyoruz. Hiçbir şeyi } \\
\text { olduğu gibi koymuyoruz. }\end{array}$ \\
\hline B Kişisi & $\begin{array}{l}\text { Bir çoğunun düşünmüyorum çünkü çok fazla efekt ve Photoshop uygulamaları } \\
\text { kullanıorlar. Bellerini inceltiyorlar falan. O yüzden düşünmüyorum. }\end{array}$ \\
\hline C Kişisi & Hayır çünkü bence bazıları olmak istediklerini atıyorlar ama bence öyle değiller. \\
\hline D Kişisi & $\begin{array}{l}\text { Çoğu zaman hayır çünkü hoş ve mutlu görünen fotoğrafları paylaşmayı tercih } \\
\text { ediyoruz daha çok ve sadece o yönümüzü yansıtmış oluyoruz. Bu da bizi sürekli } \\
\text { mutlu görünmemizi sağlıyor halbu ki öyle değil. }\end{array}$ \\
\hline E Kişisi & $\begin{array}{l}\text { Kendilerini yansıtıyorlar. Kendi yaşamlarını yansıtıyorlar çünkü sonuçta } \\
\text { Instagram ucu açı birşey. İnsanlar iş dünyasında kendi fotoğrafını paylaşıor. } \\
\text { Kendini paylaşıyor, evini paylaşıyor, okulunu paylaşıyor. Zaten kendi çalışma } \\
\text { alanlarını paylaştıkları için kendilerini yansıttıklarını düşünüyorum. }\end{array}$ \\
\hline F Kişisi & Hayır kesinlikle yansıttığını düşünmüyorum. Bazıları mesela Instagram'da abuk \\
\hline
\end{tabular}




\begin{tabular}{|l|l|}
\hline & $\begin{array}{l}\text { subuk şeyler giydiğini görüyorum. Mesela havalı havalı gözüktüğünü, mesela } \\
\text { arabalarla fotoğraf çekildiğini görüyorum. Yansıttığını düşünmüyorum. }\end{array}$ \\
\hline G Kişisi & $\begin{array}{l}\text { İnsanlar kendilerini genel olarak ifade etmiyorlar ve göstermiyorlar. Önlerine } \\
\text { perde çekmişler öndeki başka bir insan arkadaki farklı bir insan oluyor. } \\
\text { Instagramdaki benzeri aslında. O olmuyor. Olmak istediği oluyor. }\end{array}$ \\
\hline H Kişisi & $\begin{array}{l}\text { Vallahi herkesin yansıttığını düşünmüyorum açıçası. Zaten artık para kazanma } \\
\text { yeri oldu. Bir biz onu şey yapamadı ama (...) İnsanlar artık çoğu yalan dolan } \\
\text { aslında kendilerinden ziyade insanlara bir şey anlatma veya bi hava, farklı bi } \\
\text { anlayış var. Çoğu insanın ben kendini yansıttığını düşünmüyorum. Hatta kendini } \\
\text { şu şekilde para kazanmayı geçtim normal bir insan bile kendi ruhunu farklı bir } \\
\text { şekilde anlatıyor. Şu yukardayım, ego yüksek (...) Halbu ki öyle bir insan değil } \\
\text { ama dışarıya kendini farklı anlatmaya çalışıyor. O da yanlış. }\end{array}$ \\
\hline
\end{tabular}

Tablo 13'e baktığımızda E kişisi dışında katılımcıların hepsi insanların Instagram üzerinde tam anlamıyla kendilerini yansıtmadı ̆̆ konusunda hemfikir. A kişisi hiç bir şeyi olduğu gibi paylaşmadığımızı belirtiyor. B kişisi bazı insanların rötuş programlarıyla bellerini incelttiğini söylemekte. D kişisi kişilerin hep mutlu olduğu zamanlarını paylaştığını belirtmekte. F ve H kişileri insanların havalı ve egolu gözükmeye çalıştıklarını belirtiyor. G kişisi ise insanların Instagram üzerinden olmak istedikleri kişiyi yansıttıklarını düşünüyor.

Tablo 14: Katılımcilar instagramda kendini yansitıyor mu?

\begin{tabular}{|l|l|}
\hline Soru 14 & $\begin{array}{l}\text { Sizce instagramda siz kendinizi mi yoksa olmak istediğiniz kişiyi mi } \\
\text { yansıtıyorsunuz? Neden? }\end{array}$ \\
\hline A Kişisi & $\begin{array}{l}\text { Bence olmak istediğim kişiyi yansıtıyorum. İnsan dikkat çekmek istiyor. Güzel } \\
\text { olmak istiyor mesela ya da güzelsindir ama farklı şeyler yapmak istiyorsundur. } \\
\text { Ona göre paylaşıyorum. }\end{array}$ \\
\hline B Kişisi & Kendimi yansıtıorum. \\
\hline C Kişisi & Ben kendimi yansıtıyorum. \\
\hline D Kişisi & $\begin{array}{l}\text { Olmak istediğim kişiyi yansıtıyorum çünkü olduğum kişiyi yansıtmak sıkıcı olur } \\
\text { ve olduğun kişiyi yansıtmak da çoğu kişiyi ilgilendirmez. Benimle ilgili olmayan } \\
\text { da olabilir. Benim mutlu bir günüm diğer insanları da ilgilendirir. Sevdiğim bir } \\
\text { şey diğer insanları da ilgilendirir. Yani asıl olduğum kişiyi zaten herkes tanıyor. } \\
\text { Onu oraya koymamın bir anlamı yok. }\end{array}$ \\
\hline E Kişisi & $\begin{array}{l}\text { Olmak istediğim kişiyi yansıtmak için Instagrama ihtiyaç duyulmadığını } \\
\text { düşünüyorum. O kişiyi ancak çok çalışarak paylaşabilirim. Onun dişında kendimi } \\
\text { paylaşıyorum. Olmak istediğim kişi zaten benim aklımda bir yerlerde. Olmak } \\
\text { istediğim kişi zaten ilerleyen zamanlarda çıacağ1 için Instagrama gerek } \\
\text { duymuyorum. }\end{array}$ \\
\hline F Kişisi & $\begin{array}{l}\text { Olmak istediğimi yansıtmak istiyorum. Bazen direkt Instagramda mesela fotoğraf } \\
\text { atmak istersem direkt efekt falan kullanmama gerek olmuyor. Direkt atıyorum. } \\
\text { Havalı gözükeceksem yakışıklı gözükmenin bi anlamı yok benim için. Zaten } \\
\text { Instagramda neysen dışarıda da osundur. }\end{array}$ \\
\hline G Kişisi & $\begin{array}{l}\text { Ben kendimi yansıttıorum. Çünkü doğal halim daha güzel oluyor. Gerçekçilik en } \\
\text { güzeli. İnsanları kandırmamak lazım. }\end{array}$ \\
\hline H Kişisi & $\begin{array}{l}\text { Ben kendimi yansıtıyorum çünkü öyle bir çabam yok. Olmak istediğim kişi gibi } \\
\text { bir çabam yok. Bu işten para kazanmak veya bir yerlere gelmek için öyle bir } \\
\text { lüksüm de yok. Normal içimden ne geliyorsa onu atıyorum ben ama herkes öyle } \\
\text { değil. Arkadaş çevremde bunlardan var yani. }\end{array}$ \\
\hline
\end{tabular}


Tablo 14' e göre katılımcıların A, D ve F kişileri olmak istedikleri kişiyi yansıttıklarını söylemektedirler. B, C, G, H kişileri kendilerini yansıttıklarını ifade ediyorlar. E kişisi olmak istediği kişi için Instagrama ihtiyaç duymadığını zamanla zaten olacağını belirtiyor. Bu yorumdan E kişisinin de kendisini yansıttığı sonucuna varabiliriz.

\section{SONUÇ}

Sanal bir ortam olan Instagramda kullanıcılar paylaşmış oldukları paylaşımlarda bilerek ya da bilmeden kendilerini semboller üzerinden kitlesel olarak ifade etmektedirler. Bu semboller hem metalar hem de çeşitli davranışlardan oluşmaktadır. Lacan'ın kuramı çerçevesinde bu durum sembolik benliğin temsilini oluşturmaktadır. Önceden semboller sayesinde kişinin bulunmuş olduğu çevrede ifade edilmeye çalışılan sembolik benlik, Instagram sayesinde kitlesel ve paylaşımın durduğu sürece ifade edilmektedir. Bu sayede birey daha fazla kişiye kendisini ifade edebilmektedir.

Araştırma sonucunda katılımcıların beğeni sayısını dikkate almaları, çok beğeninin havalı gözükmesi ve bir katılımcının az beğeni alan fotoğrafını kaldırdığını ifade etmesi gibi yorumlar göz önünde bulundurulduğunda şöyle bir kanıya varabiliriz. Instagramda yapılan paylaşımın almış olduğu beğeni, paylaşımı yapan kişi için benliğin doğrulanması anlamına gelmektedir. Alınmış olan beğeni sayısı paylaşımı yapan kişi için bu yüzden önemlidir. Bu bağlamda diğer kullanıcıların yapmış oldukları yorumlarında kişinin sembolik benliğinin temsiline yapılmış olan bir yorum olduğu sonucuna varabiliriz. Daha geniş bir çerçeveden bakıldığında kitle iletişim araçları tarafından (daha çok reklamlar tarafından) metalara yüklenmiş olan anlamlar, tüketiciler tarafından satın alınıp ya da kullanılarak bir benlik temsili oluşturulur. Oluşturulmuş olan bu temsil instagram üzerinden bir imaj olarak kitlelere paylaşılır. Bu paylaşım diğer kullanıcılar tarafından paylaşım yapan kişi tatmin olana kadar beğenilirse ve/veya yorum yapılırsa kişi tarafından kişinin benliği doğrulanmış olur. Bu gerçekleşmediği taktirde paylaşım kullanıcıya benliğinin doğrulanmamış olduğunu gösterir.

$\mathrm{Bu}$ sistem içerisinde meta ve çeşitli nesnelere yüklenen anlam haricinde mekanlar ve bireylerde bir sembole dönüşmektedir. Bireyler instagramda yapmış olukları paylaşımlarda benliklerini ifade edebilecekleri şekilde metaları ya da mekanları bir sembol olarak kullanabilirler. Görsel olarak mekanın ifade edilemeyeceği noktada paylaşımın çekilmiş olduğu mekan “Konum bildirimi" yapılarak diğer kullanıcılara karşı belirtilebilir.

Daha önce yukarıda belirtilmiş olan sosyal grupların nerelerde zaman geçirdikleri ve ne yiyip içtikleri üzerinden kimliklerini belli etmeleri instagram üzerinden paylaşılan fotoğraflarda da kendisini bir sembol olarak göstermektedir. Derinlemesine görüşmede de bu konu ile ilgili sorulara katılımcıların sadece özel mekanlarda ya da herkesin gidemeyeceği yerlerde konum bildirimi yapması gibi vermiş oldukları cevaplar bu durumu desteklemektedir.

Kişiler yine Postmodern tüketim bölümünde bahsedilen alt statü gruplarının üst grupların tüketim alışkanlıklarını tüketmeye çalışarak sosyal statülerini yükseltmeye çalıştığı bölümü göz önünde bulundurduğumuzda. Kişilerin instagram üzerinden yapmış oldukları "Konum bildirim" li mekan paylaşımları ve kendilerini önemli bir mekanda çektikleri paylaşımları 
mekanın imajlaştırılarak sembol olarak kullanımı olarak değerlendirebiliriz. Burada kişilerin amacı kendilerini hedeflemiş oldukları statüde ve yaşam tarzında mekanlar üzerinden göstermektir.

\section{KAYNAKÇA}

Balkaya D. (2013). Özerk Dil Dizgesinden Lacan'ın Simgesel Düzenine. Konya: Çizgi Kitabevi

Batı U. (2012). Reklamın Dili. İstanbul:Alfa yayınları

Barthes R. (2011). Çağdaş Söylenler,(T. Yücel, Çev.). İstanbul:Ayrıntı yayınları

Barthes R. (2012). Göstergebilimsel Serüven,(M. Rifat ve S. Rifat, Çev.). İstanbul: Yapı Kredi Yayınları

Bauman Z. (2013). Sosyolojik Düşünmek, (A. Yılmaz, Çev.). İstanbul:Ayrıntı yayınları.

Bocock R. (2009). Tüketim,(İ. Kutluk, Çev.). Ankara: Dost Kitapevi

Çoban, B. (2005), "Aynalar Şövalyesi ya da Bilinçdışının Kaşifi LACAN” Şu kitapta: Haz. Nurdoğan Rigel, Gül Batuş, Güleda Yücedoğan ve Barış Çoban. Kadife Karanlık 21.yüzyıl iletişim çağını aydınlatan kuramcılar. İstanbul: Su Yayınları, 277-294

Dağtaş, E., ve Banu Dağtaş (2006). Tüketim Kültürü, Yaşam Tarzları, Boş Zamanlar ve Medya Üzerine Bir Literatür Taraması. Bilim Eğitim Toplum Dergisi, 14 (4), ss.4-31

Debord G. (2012). Gösteri Toplumu (A. Ekmekçi ve O. Taşkent, Çev.). İstanbul:Ayrıntı yayınları

Harvey, D. (2012), Postmodernliğin Durumu, (S. Savran, Çev.), İstanbul: Metis yayınları

Homer, S. (2013). Jacques Lacan (A. Aydın, Çev.). Ankara: Pohenix Yayınevi

Kahraman M. (2010). Sosyal Medya 101 Pazarlamacılar için Sosyal Medyaya Giriş. İstanbul: Mediacat Kitaplar1

Featherstone M. (2013). Postmodernizm ve Tüketim Kültürü (M. Küçük, Çev.). İstanbul:Ayrıntı yayınları

Fulford R. (2014). Anlatının Gücü Kitle Kültürü Çağında Hikayecilik (E. Kardelen, Çev.). İstanbul: Kolektif Kitap Bilişim ve Tasarım Ltd. Şti.

Mencütekin, M. (2014). Lacan ve Sinema Sanatı. İstanbul: Arı Sanat Yayınevi

Robins K.(2013). İmaj Görmenin Kültür ve Politikası, (N. Türkoğlu, Çev). İstanbul: Ayrıntı Yayınları

Taylan, E. (2014 Nisan). Türkiyede cinsiyet, yaş ve mezun olunan okula göre sostal medya kullanımi[WebrazziPRO]. www.webrazzi.com: https://webrazzi.com/2014/04/19/ turkiyede-cinsiyet-yas-ve-mezun-olunan-okula-gore-sosyal-medya-kullanimiwebrazzi-pro/

Tura ,S.M. (2012). Freud'dan Lacan'a Psikanaliz. İstanbul: Kanat Yayınları

TÜIK(2018). http://www.tuik.gov.tr/PreIstatistikTablo.do?istab_id=2599

Yaylagül, L. ( 2010). Kitle İletişim Kuramları. Ankara: Dipnot Yayınları

Yıldırım A., Hasan Şimşek (2013), Sosyal Bilimlerde Nitel Araştırma Yöntemleri, Ankara:

Seçkin Yayıncılık 